\title{
Effect of Thymus vulgaris $L$. and Origanum vulgare $L$. essential oils on toxicity, food consumption, and biochemical properties of lesser mulberry pyralid Glyphodes pyloalis Walker (Lepidoptera: Pyralidae)
}

\author{
Elham Yazdani ${ }^{1}$, Jalal Jalali Sendi ${ }^{1,2 *}$, Jalil Hajizadeh ${ }^{1}$ \\ ${ }^{1}$ Department of Plant Protection, Faculty of Agricultural Sciences, University of Guilan, 41635-1314 Rasht, Iran \\ ${ }^{2}$ Department of Sericulture, Faculty of Agricultural Sciences, University of Guilan, 41635-1314 Rasht, Iran
}

Received: May 26, 2013

Accepted: January 20, 2014

\begin{abstract}
The essential oils of Thymus vulgaris L. and Origanum vulgare L. were investigated for their toxicity and physiological aspects on the lesser mulberry pyralid Glyphodes pyloalis Walker in controlled condition $\left(24 \pm 1^{\circ} \mathrm{C}, 75 \pm 5 \% \mathrm{RH}\right.$ and $\left.16 \mathrm{~L}: 8 \mathrm{D}\right)$. The leaf disc method was used to study acute toxicity, the effect of $\mathrm{LC}_{10}, \mathrm{LC}_{30}$, and $\mathrm{LC}_{50}$ on the feeding efficiency of 4th instar larva, and biochemical indices. The essential oil doses of $\mathrm{LC}_{10}, \mathrm{LC}_{30}$ and $\mathrm{LC}_{50}$ were estimated to be $0.107 \%, 0.188 \%$ and $0.279 \%$ for $\mathrm{T}$. vulgaris, and $0.67 \%, 1.173 \%$ and $1.728 \%$ for $O$. vulgare, respectively. The results showed that T. vulgaris was more toxic than O. vulgare. The essential oil sublethal dose $\mathrm{LC}_{30}$ affected the nutritional indices of 4th instar larvae of G. pyloalis. The essential oils reduced total protein, carbohydrate, and lipid. Some concentrations of essential oils changed the activity level of $\alpha$-amylase, protease, lipase, general esterases, and glutathione S-transferase (GST) but others showed no effect on these enzymes. It was concluded that the used essential oil concentrations were both toxic to G. pyloalis and showed irreversible effects on key metabolic processes, therefore, the used essential oil concentrations may be considered as alternatives to the classic pest control agents.
\end{abstract}

Key words: Glyphodes pyloalis, lesser mulberry pyralid, Origanum vulgare, Thymus vulgaris

\section{Introduction}

On mulberry farm fields, the lesser mulberry pyralid is a monophagous and important pest. This pest was reported for the first time from Punjab, Pakistan in 1928 (Mathur 1980), and in 2002, from mulberry orchards in northern Iran (Jafari Khaljiri et al. 2006). The amount of food eaten by the 1st and 2nd instar larvae is negligible, but feeding increases in later instars. 4th and 5th instar larvae secrete fine threads which are able to fold the leaves. Then, these instars feed on the mesophyll inside the folds. The instars leave behind their black feces which cause loss of quality in mulberry leaves for silkworm rearing. 5th instar larvae feed on the whole leaf until only the ribs remain (Khosravi and Sendi 2010).

Currently, synthetic insecticides are most often used to control these pests. However, concerns over the development of resistance, toxicity, and environmental pollution associated with conventional synthetic insecticides compel us to look for new compounds (Coscolla 2004). There is an imperative need for safer, alternative, cropprotection agents, such as biopesticides and antifeedants (Sadek 2003). Among biopesticides, botanical pesticides have received a great deal of attention because of their favorable ecotoxicological properties, e.g. low human toxicity, rapid degradation, and reduced environmental impact. These properties make them suitable insecticides for organic agriculture (Shaaya et al. 1991, 1997; RegnaultRoger 1997). Natural products used as insecticides may have less of an environmental impact due to shorter latency, which means possible reduced resistance (Hardin et al. 2009). Certain plant families, particularly Meliaceae, Rutaceae, Labiateae, Asteraceae, Convolvulaceae, and Pedaliaceae are viewed as exceptionally promising sources of plant-based insecticides (Schmutterer 1990; Isman 2000). The extracts and essential oils have demonstrated antimicrobial and insecticidal activity (Deans and Svoboda 1989; Regnault-Roger et al. 2004; Pavela 2006).

Recently, essential oils used as an alternative pest control technology, have become popular because of their specificity to pests, their biodegradable nature, and their potential for commercial application (Liu et al. 2006). The insecticidal activity of several plant essential oils, powders, and other extracts has been evaluated against several insect pests of cereals and legumes. These oils and powders were found to have contact toxicity (Asawalam et al. 2006; Ogendo et al. 2008), repellence (Kéita et al. 2001; Rosman et al. 2007), fumigant toxicity (Lee et al. 2003; Rajendran and Muriladharan 2005), and antifeedant effects (Saxena et al. 1992). 
Secondary metabolites from plants are deleterious to insects and other herbivores in diverse ways, such as acute toxicity, enzyme inhibition, and interference with consumption and/or utilization of food (Lindroth 1991; Senthil Nathan et al. 2006). In many cases, however, the modes of action for these metabolites are unknown. In an effort to determine the effects of, and herbivore responses to dietary allelochemicals, their consumption of food is often quantified and various food utilization efficiencies are calculated (Waldbauer 1968; Slansky and Scriber 1985).

The objective of this study was to explore the toxic effects, and the sublethal effects if any, of the essential oils extracted from Thymus vulgaris L. and Origanum vulgare L. The nutritional indices, digestive and detoxifying enzymes of Glyphodes pyloalis Walker were taken into consideration.

\section{Materials and Methods}

\section{Insect rearing and an evaluation of the insecticidal efficiency of the essential oils}

The 5th instar larvae of the lesser mulberry pyralid were collected from infested mulberry orchards of the Iranian Silk Worm Research Center located in Pasikhan (Guilan province, northern Iran). These orchards produced organically-grown mulberries. The collected larvae were reared in a growth chamber in controlled conditions $\left(24 \pm 1^{\circ} \mathrm{C}, 75 \pm 5 \%\right.$ relative humidity $-\mathrm{RH}$, and $16 \mathrm{~L}: 8 \mathrm{D} \mathrm{h}$ photoperiods) and reared on fresh mulberry leaves (Kenmochi variety). Adult moths were placed in transparent, $20 \times 6 \mathrm{~cm}^{2}$ jars. Adults were provided with fresh mulberry leaves for egg-laying. Cotton wool soaked in 10\% honey was provided for feeding. Fourth larval instars were used in the subsequent experiments.

\section{Preparation of the essential oils}

T. vulgaris was collected from Masoule (northern Iran) and O. vulgare from Lahijan (northern Iran). The herbs were dried in the shade, and hand-ground to a powder. Dried herb powder (50 g) was briefly mixed with $750 \mathrm{ml}$ distilled water, and after $24 \mathrm{~h}$ was transferred to the Clevenger-type apparatus according to the method recommended in British Pharmacopoeia. Distillation lasted about $2 \mathrm{~h}$, and then the essential oil was obtained. This process was repeated several times in order to receive the required amount. The oil phase was isolated from the obtained solution. Sodium sulfate was used for dehydration.

\section{Bioassay}

Prior to the experimental phase, larvae were starved for $4 \mathrm{~h}$. Preparatory tests were initially performed to find the effective dose ranges. Four concentrations $(0.8 \%, 0.4 \%$, $0.2 \%$, and $0.1 \%$ for T. vulgaris and $1.8 \%, 1.5 \%, 1.2 \%$, and $0.9 \%$ for $O$. vulgare) were determined to be the effective doses. This experiment was performed in 4 replications with 10 larvae of 4 th instars $(<24 \mathrm{~h})$ in each replication.
The fresh leaf discs were cut from mulberry leaves $(8 \mathrm{~cm}$ diameter) and were immersed in different concentrations of the essential oils for $10 \mathrm{sec}$ and then air-dried. Each dish contained a disc. Ten larvae were released into each dish and allowed to feed. The control leaves were treated with methanol and air-dried. After $48 \mathrm{~h}$ the numbers of dead larvae were recorded. The values of $\mathrm{LC}_{10}, \mathrm{LC}_{30}$ and $\mathrm{LC}_{50}$ were estimated using Polo-PC software (LeOra 1987).

\section{Efficiency measures of quantitative food utilization}

To evaluate the effect of essential oil on the nutritional physiology in larvae of G. pyloalis, $8 \mathrm{~cm}$ diameter discs of mulberry were prepared. All weights were measured using a monopan balance accurate to $0.1 \mathrm{mg}$ (Sartorius GMBH, Type: A 120 S). Leaf discs were dipped in a $\mathrm{LC}_{30}$ concentration of essential oil for $10 \mathrm{sec}$. The control leaves were treated with methanol and air dried. A gravimetric method was used to determine weight gain, food utilization, and feces produced by the larvae. Nutritional indices were evaluated on the basis of dry weight. The newly molted 4th instar larvae were used for this experiment. The larvae were starved $4 \mathrm{~h}$ (10 larvae/concentration), and then allowed to feed on weighed quantities of treated and untreated leaves. Four replicates were carried out $(n=40)$. Leaves were weighed individually and placed in Petri dishes ( $8 \mathrm{~cm}$ diameter) for larvae to feed on. After measuring the initial weight of the larvae, they were individually introduced into separate containers. After $24 \mathrm{~h}$ the remains of leaves were replaced by newly treated leaves. The remaining leaves were weighed at the end of $24 \mathrm{~h}$ and placed in an oven $\left(45^{\circ} \mathrm{C}\right)$ for $48 \mathrm{~h}$ and reweighed in order to calculate the dry weight of the consumed food. The dry weight of the consumed food was estimated on the basis of the dried weight of the total food provided to the insect. The feces produced each day was collected, and then oven dried and weighed to estimate the dry weight of the excreta. The weights of the larvae were recorded at the end of the day. A few larvae with similar biological and physiological conditions to the experimental insects, were weighed, and dried in the oven $\left(45^{\circ} \mathrm{C}\right)$ for $48 \mathrm{~h}$ then reweighed for determining the dry weight of each larva. The duration of the experiment was three days, and the observations were recorded daily. Nutritional indices were calculated using the formula described by Waldbauer (1968):

- approximate digestibility:

$$
\mathrm{AD}=(\mathrm{E}-\mathrm{F}) / \mathrm{E} \times 100(\%),
$$

- efficiency of conversion of ingested food:

$$
\mathrm{ECI}=\mathrm{P} / \mathrm{E} \times 100(\%),
$$

- efficiency of conversion of digested food:

$$
\mathrm{ECD}=\mathrm{P} /(\mathrm{E}-\mathrm{F}) \times 100(\%),
$$

- relative growth rate:

$$
\mathrm{RGR}=\mathrm{P} / \mathrm{TA}(\mathrm{mg} / \mathrm{mg} / \text { day }),
$$

- relative consumption rate:

$$
\mathrm{RCR}=\mathrm{E} / \mathrm{TA}(\mathrm{mg} / \mathrm{mg} / \text { day }),
$$

where: A - dry weight of the insect over unit time (mg), E - dry weight of food consumed (mg), F - dry weight of feces produced (mg), P - dry weight gain of insect (mg), $\mathrm{T}-$ the duration of the experimental period (day). 


\section{Preparation of samples for enzymatic assay}

Leaf discs were initially treated with $\mathrm{LC}_{10}, \mathrm{LC}_{30}$, and $\mathrm{LC}_{50}$ concentrations of essential oil. In each experiment, 10 insects were tested with 4 replicates for each concentration. After $48 \mathrm{~h}$, the live larvae were randomly selected and their guts were removed. Dissection was done under a stereomicroscope (Olympus, SZX12), in ice-cold buffer (Salin buffer). A certain number of larvae were placed in $2 \mathrm{ml}$ of distilled water or buffer related to each test. Samples were then homogenized. The homogenates were centrifuged at $4^{\circ} \mathrm{C}$ for $10 \mathrm{~min}$. The resulting supernatants were transferred into new micro-tubes and frozen at $-20^{\circ} \mathrm{C}$ for further use.

\section{Assay of $\alpha$-amylase activity}

The $\alpha$-amylase activity was assayed by the dinitrosalicylic acid (DNS) procedure (Brenfeld 1955). As a substrate, $1 \%$ soluble starch (Merk, Darmstadt, Germany) was used. Ten microliters of the enzyme were incubated for $30 \mathrm{~min}$ at $35^{\circ} \mathrm{C}$ with $80 \mu \mathrm{l}$ universal buffer (glycine, mes (2-[morpholino] ethansulphonic acid), succinate, $\mathrm{NaOH}$, double distilled water) and $20 \mu \mathrm{l}$ soluble starch. In order to stop the reaction, $90 \mu \mathrm{l}$ DNS was added and the mixture was heated in boiling water for $10 \mathrm{~min}$. DNS is a color reagent and the reducing groups released from starch by $\alpha$-amylase action were measured by the reduction of 3,5-dinitrosalicylic acid. A standard curve of $\alpha$-amylase absorbance against the amount of released maltose was constructed to enable the calculation of the amount of maltose released during the $\alpha$-amylase assay. All assays were performed in four replicates. Absorbance was measured at $540 \mathrm{~nm}$ after cooling in ice for $5 \mathrm{~min}$.

\section{Assay of lipase activity}

The activity of lipase was estimated using the method of Tsujita et al. (1989). Ten $\mu \mathrm{l}$ of homogenate was mixed with $18 \mu \mathrm{l}$ p-nitrophenyl butrate $(50 \mathrm{mM})$ as the substrate, and mixed with $172 \mu$ universal buffer $(1 \mathrm{M})(\mathrm{pH}=7)$. This mixture was incubated at $37^{\circ} \mathrm{C}$. The absorbance was read at $405 \mathrm{~nm}$.

\section{Assay of protease activity}

The protease activity of larval guts was determined using azocasein $1 \%$ as the substrate (Garcia-Carreno and Haard 1993). Each gut was centrifuged in $10 \mu \mathrm{l}$ distilled water, then $10 \mu \mathrm{l}$ of supernatant and $15 \mu \mathrm{l}$ of buffer $(\mathrm{pH}=8)$ with $50 \mu$ l of substrate were reacted for $3 \mathrm{~h}$ at $37^{\circ} \mathrm{C}$. Proteolysis was stopped by the addition of $150 \mu \mathrm{l}$ of $10 \%$ trichloroacetic acid (TCA). The solution was transferred to $4^{\circ} \mathrm{C}$ in a refrigerator for $30 \mathrm{~min}$, and the reaction mixture was centrifuged at $13,000 \mathrm{~g}$ for $10 \mathrm{~min}$. One hundred $\mu \mathrm{l}$ of supernatant was mixed with $100 \mu \mathrm{l} 1 \mathrm{~N} \mathrm{NaOH}$ and the absorbance was read at $440 \mathrm{~nm}$.

\section{Assay of esterase activity}

The activities of general esterases were determined according to the Van Asperen (1962) method. In this experi- ment, $\alpha$-naphtylacetate ( $\alpha$-NA) and $\beta$-naphtylacetate $(\beta$ -NA) were used as substrates. One gut was homogenized with $1,000 \mu \mathrm{l} 0.1 \mathrm{M}$ phosphate $(\mathrm{pH}=7)$ containing Triton $\mathrm{X}-100$ at a ratio of $0.01 \%$, then the homogenized solution was centrifuged at $10,000 \mathrm{~g}$ for $10 \mathrm{~min}$ at $4^{\circ} \mathrm{C}$. The supernatant was transferred to a new micro-tube and was diluted with phosphate buffer. This solution reacted with the substrate and by using dye indicator (Fast Blue RR salt) $(1 \mathrm{mM})$ a colored solution was formed. The absorbance was read at $630 \mathrm{~nm}$.

\section{Assay of glutathione S-transferase (GST)}

The activity of GST was determined according to the method of Habing et al. (1974). As the substrate, 1-chloro-2,4-dinitrobenzene (CDNB) $(20 \mathrm{mM})$ was used. Initially a larva was homogenized in $20 \mu \mathrm{l}$ distilled water, then the homogenized solution was centrifuged at $12,500 \mathrm{~g}$ for $10 \mathrm{~min}$ at $4^{\circ} \mathrm{C}$. Fifteen $\mu \mathrm{l}$ of supernatant was mixed with $135 \mu \mathrm{l}$ of phosphate buffer ( $\mathrm{pH}=7), 50 \mu \mathrm{l}$ of CDNB and $100 \mu \mathrm{l}$ of GST. The absorbance was read at $340 \mathrm{~nm}$.

\section{Estimation of protein}

The method of Bradford (1994) was used for determining the protein total. First, each larva was homogenized in $350 \mu \mathrm{l}$ of distilled water and samples were centrifuged at $10,000 \mathrm{rpm}$ for $5 \mathrm{~min}$ at $4^{\circ} \mathrm{C}$. Next, $10 \mu \mathrm{l}$ of supernatant was mixed with $90 \mu \mathrm{l}$ of distilled water and 2,500 $\mu \mathrm{l}$ of dye (10 mg powder of Coomassie Brilliant Blue, BioRed, Munchen, Germany) in $5 \mathrm{ml}$ ethanol $96 \%$ and $10 \mathrm{ml}$ phosphoric acid $85 \%(\mathrm{w} / \mathrm{w})$. This solution was brought to $100 \mathrm{ml}$ with distilled water. Bovin serum albumin was used as the standard. The absorbance was read at $630 \mathrm{~nm}$.

\section{Estimation of lipid and carbohydrate}

Determination of lipids and carbohydrates was performed according to Yual et al. (1994). Larvae were homogenized individually in $100 \mu \mathrm{l}$ of $\mathrm{Na}_{2} \mathrm{SO}_{4} \%$. Lipids and carbohydrates were extracted in $750 \mu$ of chloroform : methanol $(1: 2)$. Individual tubes were centrifuged for $10 \mathrm{~min}$ at $8,000 \mathrm{rpm}$ at $4^{\circ} \mathrm{C}$. After that, $500 \mu \mathrm{l}$ were taken from each tube and dried at $40^{\circ} \mathrm{C}$. Samples were then dissolved in $500 \mu \mathrm{H}_{2} \mathrm{SO}_{4}$ and incubated for $10 \mathrm{~min}$ at $90^{\circ} \mathrm{C}$ in a water bath. Samples of $30 \mu \mathrm{l}$ were placed into wells on Elisa plates together with $270 \mu \mathrm{l}$ of vanillin reagent (600 mg vanillin dissolved in $100 \mathrm{ml}$ distilled water and $\left.400 \mathrm{ml} 85 \% \mathrm{H}_{3} \mathrm{PO}_{4}\right)$. After $30 \mathrm{~min}$, the absorbance was read at $530 \mathrm{~nm}$. The lipid total was calculated from the standard curve of cholesterol.

To determine the amount of carbohydrate in each larva, $150 \mu \mathrm{l}$ was taken from the chloroform : methanol extract, and then $100 \mu \mathrm{l}$ distilled water was added along with $500 \mu \mathrm{l}$ of anthrone (500 mg of anthrone dissolved in $500 \mathrm{ml} \mathrm{H}_{2} \mathrm{SO}_{4}$ ). For reaction to take place, the samples were placed at $90^{\circ} \mathrm{C}$. Then, $250 \mu \mathrm{l}$ of the sample were placed in the Elisa plates. The absorbance was read at $630 \mathrm{~nm}$ and the carbohydrate level was calculated using a standard curve. 


\section{Statistical analysis}

$\mathrm{LC}_{10} \mathrm{LC}_{30}$, and $\mathrm{LC}_{50}$ of the toxicity bioassay were calculated with Polo-PC (LeOra 1987). Data from nutritional indices and enzymes activity were compared by one-way analysis of variance (ANOVA). Differences between the various treatments were determined at $5 \%$ by Tukey's multiple range tests using SAS software (SAS 1997).

\section{Results}

\section{Bioassay}

The $\mathrm{LC}_{10}, \mathrm{LC}_{30}$, and $\mathrm{LC}_{50}$ values of T. vulgaris and O. vulgare $48 \mathrm{~h}$ after treatment as per confident limits and the slope of line regression are shown in table 1 . The corresponding $\mathrm{LC}_{50}$ values were respectively, $0.279 \%$ and $1.72 \%$ for T. vulgaris and O. vulgare $48 \mathrm{~h}$ after treatment.

The present study showed that essential oils of T. vulgaris and $O$. vulgare were effective against G. pyloalis larva. The lower $\mathrm{LC}_{50}$ (highest toxicity) belongs to T. vulgaris. The $\mathrm{LC}_{50}$ of T. vulgaris is 6.33 times more than O. vulgare.

\section{Effect of T. vulagris and O. vulgare essential oils on nutritional indices}

The feeding indices of 4 th instar G. pyloalis larva feeding on leaves treated with T. vulagris and O. vulgare essential oils, were affected. Our experiment showed that T. vulagris and $O$. vulgare essential oils had an intense effect on the feeding behavior and growth of G. pyloalis. The results of the effect of $\mathrm{LC}_{30}$ of T. vulgaris and O. vulgare on the feeding efficiency of 4th instar larva of G. pyloalis are shown in table 2. $\mathrm{AD}(\mathrm{F}=10.69 ; \mathrm{df}=2,6 ; \mathrm{p}=0.0042)$ was increased in larva treated with $O$. vulgare essential oil; with significant differences to that of the control. By using the essential oils, $\mathrm{RGR}(\mathrm{F}=7.33 ; \mathrm{df}=2,6 ; \mathrm{p}=0.012)$, RCR $(\mathrm{F}=2.98 ; \mathrm{df}=2,6 ; \mathrm{p}=0.101)$, and $\mathrm{ECI}(\mathrm{F}=5.13 ; \mathrm{df}=2,6$; $\mathrm{p}=0.032)$ were reduced. These indices were significantly reduced compared to the control. The RCR was lowest in the larvae treated with T. vulgaris essential oil (1.188 $\mathrm{mg} / \mathrm{mg} /$ day) and was significantly different than the control. The amount of the ECD did not show any differences when compared with the control.

Effect of T. vulagris and O. vulgare essential oils on the total protein, the carbohydrates, and the lipid

The results of the total protein, lipid, and carbohydrates in fourth instar larvae of G. pyloalis after treatment with T. vulagris and $O$. vulgare essential oils are shown in figures $1-3$. The amount of the total protein of the larva treated with $\mathrm{LC}_{30}(\mathrm{~F}=7.49 ; \mathrm{df}=2,6 ; \mathrm{p}=0.0206)$ and $\mathrm{LC}_{50}(\mathrm{~F}=46.65$; $\mathrm{df}=2,6 ; \mathrm{p}=0.0002)$ of $T$. vulagris and O. vulgare essential oils, showed differences in the treated larva in comparison with the control. All concentrations tested reduced the lipid value. The $\mathrm{LC}_{50}$ value of $T$. vulagris and $O$. vulgare essential oils reduced the amount of lipid, compared with the control $(\mathrm{F}=17.587 ; \mathrm{df}=2,6 ; \mathrm{p}<0.0001)$, and it was dose dependent. This reduction was more severe in the case of $O$. vulgare than T. vulgaris. The effect of T. vulgaris and O. vulgare on the carbohydrate activity was significant. Activity of this macromolecule in all of the treatments was concentration-dependent. The macromolecule activity declined to the lowest value with $\mathrm{LC}_{50}$ concentration (Fig. 3) $(\mathrm{F}=16.64 ; \mathrm{df}=2,6 ; \mathrm{p}<0.0001)$.

Table 1. Toxicity of O. vulgare and T. vulgaris to 4 th instar larva of G. pyloalis

\begin{tabular}{cccccc}
\hline Plants & $\mathrm{N}$ & $\begin{array}{c}\mathrm{LC}_{10} \\
(95 \% \mathrm{CL})\end{array}$ & $\begin{array}{c}\mathrm{LC}_{30} \\
(95 \% \mathrm{CL})\end{array}$ & $\begin{array}{c}\mathrm{LC}_{50} \\
(95 \% \mathrm{CL})\end{array}$ & $\begin{array}{l}\mathrm{Slope} \pm \mathrm{SE} \\
\mathrm{X}^{2}(\mathrm{df})\end{array}$ \\
\hline O. vulgare & 200 & $0.67(0.139-0.935)$ & $1.17(0.719-1.45)$ & $1.72(1.43-2.95)$ & $3.11 \pm 0.204$ \\
T. vulgaris & 200 & $0.107(0.138-0.728)$ & $0.188(0.148-0.226)$ & $0.279(0.233-0.333)$ & $3.08 \pm 0.405$ \\
\hline
\end{tabular}

CL (Confidence Limit) which has been calcutated with 95\% confidence; essential oil activity is considered significantly different when the 95\% CI (Confidence Interval) fails to overlap $\mathrm{N}$ - the number of insects used in the bioassay

Table 2. Comparison of feeding efficiency in treated 5th instar larva the and control of G. pyloalis with LC ${ }_{30}$ concentration of O. vulgare and T. vulgaris essential oils

\begin{tabular}{|c|c|c|c|c|c|}
\hline Plants & $\mathrm{AD}[\%]$ & ECI [\%] & $\mathrm{ECD}[\%]$ & RCR [mg/mg/day] & $\mathrm{RGR}$ [mg/mg/day] \\
\hline The control & $76.62 \pm 0.6 \mathrm{~b}$ & $5.20 \pm 0.68 \mathrm{a}$ & $4.87 \pm 0.89$ a & $1.45 \pm 0.07 \mathrm{a}$ & $0.066 \pm 0.003 \mathrm{a}$ \\
\hline T. vulgaris & $80.66 \pm 1.21 \mathrm{ab}$ & $2.38 \pm 0.76 \mathrm{~b}$ & $3.03 \pm 0.94 \mathrm{a}$ & $1.18 \pm 0.04 b$ & $0.031 \pm 0.008 b$ \\
\hline O. vulgare & $83.87 \pm 1.37 \mathrm{a}$ & $2.92 \pm 0.17 \mathrm{~b}$ & $2.96 \pm 0.15 \mathrm{a}$ & $1.3 \pm 0.08 \mathrm{ab}$ & $0.045 \pm 0.004 b$ \\
\hline
\end{tabular}

Within columns, means followed by the same letter do not differ significantly at $\mathrm{p}<0.05$

AD - approximate digestibility; ECI - efficiency of conversion of ingested food; ECD - efficiency of conversion of digested food; RGR - relative growth rate; $R C R$ - relative consumption rate 


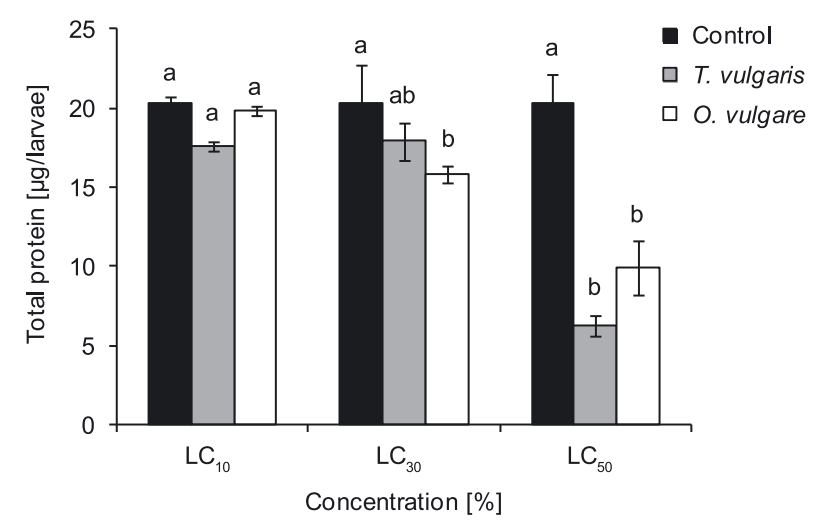

Fig. 1. Amount of total protein in 4th instar larvae of G. pyloalis after treatment with essential oils of T. vulgaris and O. vulgare. The small letters means significant at $\mathrm{p} \leq 0.05$

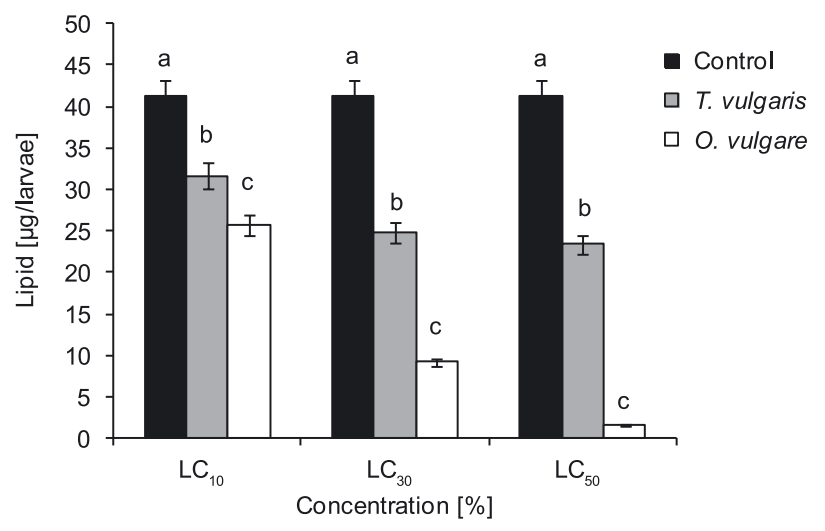

Fig. 2. Amount of total lipid in 4th instar larvae of G. pyloalis after treatment with essential oils of T. vulgaris and O. vulgare. The small letters means significant at $\mathrm{p} \leq 0.05$

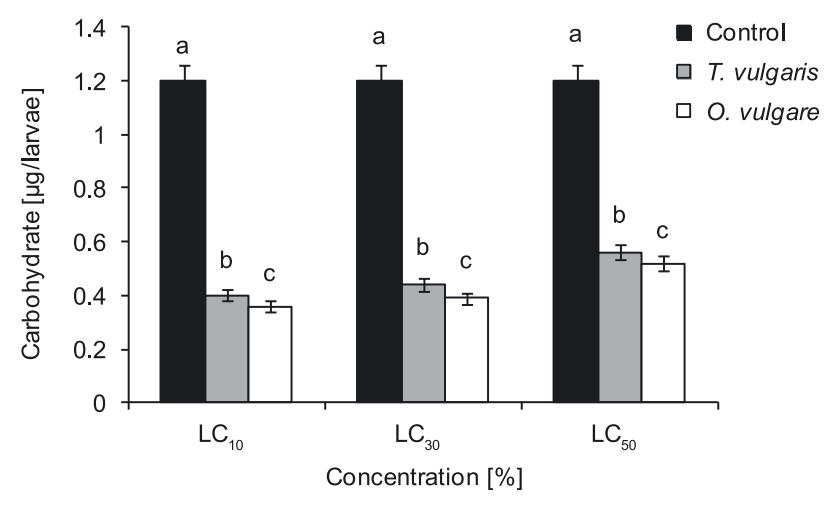

Fig. 3. Amount of carbohydrate in 4th instar larvae of G. pyloalis after treatment with essential oils of T. vulgaris and O. vulgare. The small letters means significant at $p \leq 0.05$

\section{Effects of T. vulgaris and O. vulgare essential oils on digestive enzymes}

Effects of T. vulgaris and O. vulgare essential oils on digestive enzymes after feeding on treated leaves with different concentrations $\left(\mathrm{LC}_{10}, \mathrm{LC}_{30}\right.$ and $\mathrm{LC}_{50}$ ) of both essential oils are shown in table 3 . The results indicated that the specific activity of $\alpha$-amylase sharply decreased in larvae treated with all the concentrations of $T$. vulgaris $(\mathrm{F}=27.27$; $\mathrm{df}=3,8 ; \mathrm{p}=0.0002)$ and $O$. vulgare $(\mathrm{F}=25.21 ; \mathrm{df}=3,8$; $\mathrm{p}=0.0001$ ) essential oils. This reduction was more severe in the case of O. vulgare than T. vulgaris.
The activity of lipase in 4th instar larvae of G. pyloalis treated with different concentrations of T. vulgaris essential oil, did not show significant differences as compared to the control $(\mathrm{F}=3.22, \mathrm{df}=3,8, \mathrm{p}=0.06)$, whereas the $\mathrm{LC}_{50}$ concentration $(\mathrm{F}=3.22 ; \mathrm{df}=3,8 ; \mathrm{p}=0.06)$ of $O$. vulgare significantly increased the activity of this enzyme in the larvae of G. pyloalis. The activity of protease significantly increased in the larvae treated with $\mathrm{LC}_{30}$ and $\mathrm{LC}_{50}$ concentrations of $O$. vulgare $(F=5.86 ; \mathrm{df}=3,8 ; \mathrm{p}=0.0203)$, but in the treatment using T. vulgaris essential oil, only larvae treated with the $\mathrm{LC}_{50}$ concentration differed statistically as compared to the control ( $\mathrm{F}=9.77 ; \mathrm{df}=3,8 ; \mathrm{p}=0.0047)$. 
Table 3. Activity of $\alpha$-amylase, protease, lipase, esterase, and GST enzymes in 4th instar larva of the lesser mulberry pyralid G. pyloalis after treatment with $\mathrm{LC}_{10}, \mathrm{LC}_{30}$ and $\mathrm{LC}_{50}$ concentrations of $O$. vulgare and T. vulgaris essential oils

\begin{tabular}{|c|c|c|c|c|c|c|c|}
\hline Plants & $\begin{array}{l}\text { Concen- } \\
\text { tration }\end{array}$ & $\begin{array}{c}\alpha \text {-Amylase } \\
\text { [nmol/min/mg } \\
\text { protein] }\end{array}$ & $\begin{array}{c}\text { Lipase } \\
{\left[\begin{array}{c}\mu \mathrm{mol} / \mathrm{min} / \mathrm{mg} \\
\text { protein] }\end{array}\right.}\end{array}$ & $\begin{array}{c}\text { Protease } \\
\text { [OD/min/mg } \\
\text { protein] }\end{array}$ & $\begin{array}{c}\text { GST } \\
{\left[\begin{array}{c}\mu \mathrm{mol} / \mathrm{min} / \mathrm{mg} \\
\text { protein }]\end{array}\right.}\end{array}$ & \multicolumn{2}{|c|}{$\begin{array}{c}\text { Esterase } \\
{[\mathrm{nmol} / \mathrm{min} / \mathrm{mg} \text { protein }]}\end{array}$} \\
\hline \multirow[t]{5}{*}{ O. vulgare } & & & & & & * & ** \\
\hline & the control & $0.011 \pm 7 \times 10^{-4} \mathrm{a}$ & $0.0036 \pm 4 \times 10^{-4} \mathrm{~b}$ & $1.45 \pm 0.05 \mathrm{a}$ & $0.00045 \pm 1 \times 10^{-4} \mathrm{C}$ & $0.0051 \pm 1 \times 10^{-3} \mathrm{c}$ & $0.024 \pm 4 \times 10^{-4} \mathrm{a}$ \\
\hline & $\mathrm{LC}_{10}$ & $0.0041 \pm 6 \times 10^{-4} \mathrm{~b}$ & $0.0057 \pm 2 \times 10^{-4} \mathrm{ab}$ & $1.35 \pm 0.4 \mathrm{a}$ & $0.0013 \pm 1 \times 10^{-4} \mathrm{~b}$ & $0.012 \pm 5 \times 10^{-3} \mathrm{cb}$ & $0.01 \pm 2 \times 10^{-3} \mathrm{ab}$ \\
\hline & $\mathrm{LC}_{30}$ & $0.0022 \pm 1 \times 10^{-3} \mathrm{~b}$ & $0.0062 \pm 2 \times 10^{-3} \mathrm{ab}$ & $5.74 \pm 0.4 \mathrm{~b}$ & $0.0018 \pm 6 \times 10^{-6} \mathrm{ab}$ & $0.018 \pm 3 \times 10^{-3} \mathrm{ab}$ & $0.012 \pm 3 \times 10^{-3} \mathrm{bc}$ \\
\hline & $\mathrm{LC}_{50}$ & $0.001 \pm 6 \times 10^{-4} \mathrm{~b}$ & $0.0097 \pm 1 \times 10^{-\mathrm{a}}$ & $5.54 \pm 1.9 \mathrm{~b}$ & $0.0021 \pm 1 \times 10^{-4} \mathrm{a}$ & $0.024 \pm 1 \times 10^{-2} \mathrm{a}$ & $0.020 \pm 2 \times 10^{-3} \mathrm{c}$ \\
\hline \multirow[t]{4}{*}{ T. vulgaris } & the control & $0.038 \pm 7 \times 10^{-4} \mathrm{a}$ & $0.003 \pm 4 \times 10^{-4} \mathrm{a}$ & $1.45 \pm 0.05 b$ & $0.00045 \pm 1 \times 10^{-4} \mathrm{~b}$ & $0.0051 \pm 1 \times 10^{-3} \mathrm{c}$ & $0.0051 \pm 4 \times 10^{-4} \mathrm{C}$ \\
\hline & $\mathrm{LC}_{10}$ & $0.0119 \pm 1 \times 10^{-3} \mathrm{~b}$ & $0.0074 \pm 2 \times 10^{-4} \mathrm{a}$ & $1.94 \pm 0.02 \mathrm{ab}$ & $0.00159 \pm 2 \times 10^{-4} \mathrm{a}$ & $0.017 \pm 3 \times 10^{-3} \mathrm{ab}$ & $0.0071 \pm 3 \times 10^{-4} \mathrm{c}$ \\
\hline & $\mathrm{LC}_{30}$ & $0.0112 \pm 4 \times 10^{-3} \mathrm{~b}$ & $0.0091 \pm 2 \times 10^{-3} \mathrm{a}$ & $1.35 \pm 0.2 \mathrm{~b}$ & $0.00152+2 \times 10^{-4} \mathrm{a}$ & $0.0122 \pm 3 \times 10^{-3} \mathrm{~b}$ & $0.012 \pm 2 \times 10^{-4} \mathrm{~b}$ \\
\hline & $\mathrm{LC}_{50}$ & $0.008 \pm 2 \times 10^{-3} \mathrm{~b}$ & $0.0094 \pm 1 \times 10^{-3} \mathrm{a}$ & $2.71 \pm 0.3 \mathrm{a}$ & $0.0017 \pm 4 \times 10^{-6} \mathrm{a}$ & $0.0183 \pm 1 \times 10^{-2} \mathrm{a}$ & $0.018 \pm 1 \times 10^{-3} \mathrm{a}$ \\
\hline
\end{tabular}

GST - glutathione S-transferase

* $\alpha$-Naphtylacetate substrate; ** $\beta$-Naphtylacetate substrate

Within columns, means followed by the same letter do not differ significantly at $\mathrm{p}<0.05$

\section{Effects of T. vulgaris and O. vulgare essential oils on detoxifying enzymes}

General esterase with substrate $\alpha$-naphtylacetate and $\beta$-naphtylacetate showed a significant increase compared with the control at the $\mathrm{LC}_{30}$ and $\mathrm{LC}_{50}(\mathrm{~F}=10.63 ; \mathrm{df}=3,8$; $\mathrm{p}=0.0036)$ concentrations of $O$. vulgare essential oil and at all the concentrations of $T$. vulgaris essential oil ( $\mathrm{F}=52.56$; $\mathrm{df}=3,8 ; \mathrm{p}<0.0001)$. The activity of GST was increased by all the concentrations of both of the essential oils, and the activity was significant compared with the control ( $\mathrm{F}=$ $=9.15 ; \mathrm{df}=3,8 ; \mathrm{p}<0.0001$ ).

\section{Discussion}

In this investigation, two essential oils were tested for their toxicity against larva of G. pyloalis. Our results clearly indicated that both essential oils possess insecticidal activity against lesser mulberry pyralid. The essential oil of T. vulgaris produced higher insecticidal activity against G. pyloalis. The mortality difference observed from using these oils could be due to their active volatiles; mostly monoterpenes, which are very active on insects (Liu and Ho 1999; Huang et al. 2000; Kouninki 2005). In a related study, Khosravi and Jalali (2013) stated that T. vulgaris and Lavandula angustifolia Mill. essential oils displayed strong toxicity on the elm leaf beetle Xanthogaleruca luteola Muller. Essential oil vapours from O. vulgare were toxic against the nymphs and adults of Tetranychus urticae Koch and the adults of Bemisia tabaci Gennandius (Calmasur et al. 2006).

The quality and quantity of food consumed may increasingly affect the growth, development, and the reproduction of insects (Scriber and Slansky 1981). The evaluation of the feeding indices under the $\mathrm{LC}_{30}$ concentration of T. vulgaris and O. vulgare essential oils showed that AD in larval feeding on treated leaves increased compared to the controls. Khosravi et al. (2010) reported similar results with Artemisia annua L. extract on G. pyloalis. In addition to decreases in ECI and ECD, those treatments with Thyme and Origanum essential oils also produced a significant decrease in the RCR and RGR. The results also showed that RCR and RGR were significantly lower among 4th instars larvae that were fed on a diet containing T. vulgaris and O. vulgare essential oils. We demonstrated that Thyme and Origanum oils significantly inhibited G. pyloalis larvae from feeding on mulberry leaves. Thymus vulgaris was more potent. The decreased RGR and RCR in treated larvae may indicate the toxic effects of plant allelochemicals on the peritrophic membrane and may indicate damage to the cellular surfaces of the midgut (Marie et al. 2009).

In physiological studies, the determination of the total protein and many chemical macromolecules, such as lipid and carbohydrate, is important. Proteins are major biochemical components necessary for an organism to develop, grow and perform its vital activities. The mean protein content values were determined in the 4 th instars treated with $\mathrm{LC}_{10}, \mathrm{LC}_{30}$ and $\mathrm{LC}_{50}$ concentrations of T. vulgaris and O. vulgare essential oils. From the data recorded in figure 1 , it is clear that total protein was significantly decreased with $\mathrm{LC}_{30}$ and $\mathrm{LC}_{50}$ concentrations of T. vulgaris and $O$. vulgare essential oils. The protein content in an insect is dependent upon its synthesis, breakdown, water movement between tissues, and hemolymph. The reduction in protein content in the larvae was attributed to one or a combination of factors, like a reduction in the synthesis of proteins or an increase in the breakdown of proteins to detoxify the active principles present in the plant extracts or essential oils (Vijayaraghavan et al. 2010). Similar results were obtained by Schmidt et al. (1998) by using a methanolic extract of Melia azedarach L. on the hemolymph protein of Spodoptera littoralis (Boisduval) and Agrotis ipsilon (Hufnagel).

In this investigation, lipid reduction was significant in larvae treated with all the essential oil concentrations. Reduction of lipid levels in the larvae treated with plant essential oils may be due to their effect on the lipid me- 
tabolism, and due to the utilization of lipid reserves for energy generation as a result of induced stress (Sancho et al. 1998; Olga et al. 2006).

The essential oils tested in the present study, considerably reduced the carbohydrate content of the lesser mulberry pyralid larvae. Under stress conditions, more sugars might be metabolized to meet the energy expenses. This could be the reason for the carbohydrate level depletion in the treated insects. Similar results were obtained by Seyoum et al. (2002) in desert locust, and by Khosravi et al. (2011) in G. pyloalis larva treated with A. annua extract.

The most important digestive enzymes of many insects that feed exclusively on plants during larval and/or adult life is $\alpha$-amylase. When the action of the amylases is inhibited, nutrition of the organism is impaired causing a shortness in energy (Mehrabadi et al. 2010). The results of this study indicated that $\alpha$-amylase activity in the midgut of larvae treated with O. vulgare and T. vulgaris essential oils was significantly reduced. The present results are consistent with other reports (Saleem and Shakori 1987; Lee et al. 1994; Shekari et al. 2008; Khosravi et al. 2011).

Proteases are important in digesting food and converting protein to amino acids needed for the body. Proteases play a crucial role in the food digestion of insects (Terra and Ferriera 2005). By treatments of $\mathrm{LC}_{30}$ and $\mathrm{LC}_{50}$ concentrations of T. vulgaris essential oil on 4th instar larvae of G. pyloalis, it was found that activity of this enzyme increased. But essential oil of $O$. vulgare could increase protease only at the highest concentration. Studies by Senthil Nathan et al. (2004 and 2006), Zibaee and Bandani (2010), and Khosravi and Jalali (2013) inferred that botanical insecticides may affect the construction of certain types of proteases.

Lipases are enzymes that preferentially hydrolyze the outer links of fat molecules, and have been studied in few insects. In our investigation, lipase activity was not significantly changed, but $\mathrm{LC}_{50}$ concentration of $O$. vulgare increased the activity of this enzyme. The increased activity of midgut lipase might account for a greater utilization of exogenous lipids and might result in the biomass production (Champagne et al. 1992; Desai and Desai 2000; Ahmad et al. 2006). Sujitha et al. (2010) reported that an extract of Pedaliumm murex L. increased lipase activity in Spodoptera litura (Fabricius).

Glutathione S-transferases are a major group of detoxification enzymes found in most organisms. They help to protect cells from oxidative stress and chemical toxicants by aiding the excretion of electrophilic and lipophilic compounds from the cell (Hayes and Pulford 1995). In the present study, the activity of GST in larvae treated separately with the studied essential oils, was increased compared with the control. Our results are similar to the results obtained in other studies (Vanhaelen et al. 2001; Dugravot et al. 2004; Zibaee and Bandani 2010; Khosravi et al. 2011). General esterase activity increased in the G. pylolais larva treated separately with both the essential oils used in our study. These results show that GSTs and esterases play a role in the detoxification or in the metabolism of T. vulgaris and O. vulgare essential oils.

The present investigation indicated that $T$. vulgaris and $O$. vulgare essential oils possess antifeedant and toxic effects on G. pyloalis. We also found that T. vulgaris essential oil was more toxic than $O$. vulgare essential oil. In addition, compounds present in these essential oils affect nutritional indices and the activity of macromolecules, digestive enzymes as well as the detoxifying enzymes in this pest. However, further studies are needed to explore the toxic, antifeedant and growth regulatory substances in these plants.

\section{Acknowledgements}

Financial assistance from the research department of the University of Guilan during this research program is gratefully acknowledged.

\section{References}

Ahmad M., Emam S.S., Naidia Y., Megally G. 2006. Furocouarin and quinoline alkaloid with larvacidal and antifeedant activities isolated from Ruta chalepensis leaves. J. Nat. Prod. 2: $10-22$.

Asawalam E.F., Emosairue S.O., Hassanali A. 2006. Bioactivity of Xylopia aetiopica (Dunal) A. Rich essential oil constituents on maize weevil Sitophilus zeamais Motschulsky (Coleoptera: Curculionidae). Electron. J. Environ. Agric. Food Chem. 5 (1): 1195-1204.

Bernfeld P. 1955. $\alpha$-Amylases. Methods in Enzymology 1: 149151.

Bradford M.M. 1994. A rapid and sensitive method for the quantitation of microgram quantities of protein utilizing the principle of protein dye binding. Anal. Biochem. 72 (1-2): 248-254.

Champagne D.E., Koul O., Isman M.B., Scudder G.G.E., Towers G.H.N. 1992. Biological activity of limonoids from rutales. Phytochemistry 31 (2): 377-394.

Calmasur O., Aslan I., Sahin F. 2006. Insecticidal and acaricidal effect of three Lamiaceae plant essential oils against Tetranychus urticae Koch and Bemisia tabaci Genn. Ind. Crop Prod. 23 (2): 140-146.

Coscollá R. 2004. Introducción a la protección integrada. Phytoma-Espana, Valencia, Espana, 50 pp.

Dean S.G., Svoboda K.P. 1989. Antimicrobial activity of summer savory (Satureja hortensis L.) essential oil and its constituents. J. Hortic. Sci. 64: 205-210.

Desai S.D., Desai B.D. 2000. Studies on insecticides properties of some plants. Shaspha 71: 85-88.

Dugrovot S., Thibout E., Abo-Ghalia A., Huignard J. 2004. How a specialist and a non specialist insect cope with dimethyl disulfide produced by Allium porrum. Entomol. Exp. Appl. 113 (3): 173-179.

Garcia-Carreno F.L., Haard L. 1993. Characterization of protease classes in langostilla Pleuroncodes planipes and crayfish Pacifastacus astacus extracts. J. Food. Biochem. 17 (2): 97-113.

Habing W.H., Pabst M.J., Jakoby W.B. 1974. Glutathione S-transferases: The first step in mercapturic acid formation. J. Biol. Chem. 249 (22): 7130-7139.

Hardin J.A., Fatimah L., Jackson C. 2009. Applications of natural products in the control of mosquito-transmitted diseases. Afr. J. Biotechnol. 8 (25): 7373-7378.

Hayes J.D., Pulford D.J. 1995. The glutathione S-transferase supergene family regulation of GST and the contribution of 
the isoenzymes to cancer chemoprotection and drug resistance. Crit. Rev. Biochem. Mol. Biol. 30 (6): 445-600.

Huang Y., Lam S.L., Ho S.H. 2000. Bioactivities of essential oil from Elletaria cardamomum (L.) Maton. to Sitophilus zeamais Motschulky and Tribolium castaneum (Herbst). J. Stored Prod. Res. 36 (2): 107-117.

Isman M.B. 2000. Plant essential oils for pest and disease management. Crop Prot. 19 (8-10): 603-608.

Jafari Khaljiri U., Rezaeei V., Zargarpour P. 2006. Biology of mulberry pyralid Glyphodes pyloalis Walker (Lepidoptera: Pyralidae) a new mulberry pest in Guilan province. VII Iranian Congress of Plant Protection, Tehran University, Tehran, Iran, $257 \mathrm{pp}$.

Kéita S.M., Vincent C., Schmit J.P., Arnason J.T., Bé-langer A. 2001. Efficacy of essential oils of Ocimum basilicum L. and O. gratissimum L. applied as an insecticidal fumigant and powder to control Callosobruchus maculatus (Fab.) (Coleoptera: Bruchidae). J. Stored Prod. Res. 37 (4): 339-349.

Khosravi R., Jalali Sendi J. 2010. Biology and demography of Glyphodes pyloalis Walker (Lepidoptera: Pyralidae) on mulberry. J. Asia-Pacific Entomol. 13 (4): 273-276.

Khosravi R., Jalali Sendi J., Ghadamyari M. 2010. Effect of Artemisia аппиа L. on deterrence and nutritional efficiency of lesser mulberry pyralid (Glyphodes pyloalis Walker) (Lepidoptera: Pyralidae). J. Plant Prot. Res. 50 (4): 423-428.

Khosravi R., Sendi J.J., Ghadamyari M., Yazdani E. 2011. Effect of sweet wormwood Artemisia annua crude leaf extracts on some biological and physiological characteristics of the lesser mulberry pyralid, Glyphodes pyloalis. J. Insect. Sci. 11 (156).

http:// www.insectscience.org/11.156/ [Accessed: June 28, 2013].

Khosravi R., Jalali J. 2013. Toxicity, development and physiological effect of Thymus vulgaris and Lavandula angustifolia essential oils on Xanthogaleruca luteola (Coleoptera: Chrysomelidae). J. King Saud. Univ. Sci. 25 (4): 349-355.

Kouninki H. 2005. Etudedela toxicitédes huiles essentielles de queklques plantes traditionnelles utilisées au Nord Cameroun contre les Bruchidae et Curculionidae. Mémoire de D.E.A, Université Catholique de Louvain, 82 pp.

Lee H.R., Kim J.W., Lee I. 1994. Studies on the toxicity of insect growth regulators against the fall webworm (Hyphantria cunea Drury) and the rice stem borer (Chilo supressalis Walker) comparisions in enzyme activities. Korean J. Appl. Entomol. 33 (2): 88-95.

Lee S., Peterson C.J., Coats J.R. 2003. Fumigation toxicity of monoterpenoids to several stored product insects. J. Stored Prod. Res. 39 (1): 77-85.

LeOra software. 1987. Polo-Pc: A User Guide to Probit or Logit Analysis. LeOra software. Berkely, California, 22 pp.

Lindroth L.R. 1991. Differential toxicity of plant allelochemicals to insects: roles of enzymatic detoxication systems. p. 1-33. In: "Insect-Plant Interactions" (E.A. Bernays, ed.), CRC Press, Boca Raton, FL, 74 pp.

Liu Z.L., Ho S.H. 1999. Bioactivity of the essential oil extracted from Evodia rutaecarpa Hook f. and Thomas against the grain storage. J. Stored Prod. Res. 35 (4): 317-328.

Liu C.H., Mishra A.K., Tan R.X., Tang C., Yang H., Shen Y.F. 2006. Repellent and insecticidal activities of essential oils from Artemisia princeps and Cinnamomum camphora and their effect on seed germination of wheat and broad bean. Bioresour Technol. 97 (15): 1969-1973.
Marie S.S., Amr E.M., Salem N.Y. 2009. Effect of some plant oils on biological, physiological and biochemical aspects of Spodoptera littoralis (Boisd.). Res. J. Agric. Biol. Sci. 5 (1): 103-107.

Mathur R.N. 1980. Biology of the mulberry defoliator Glyphodes pyloalis (Walk) (Lepidoptera: Pyralidae). Ind. Forest Bull. 271: 1-6.

Mehrabadi M., Bandani A.R., Saadati F. 2010. Inhibition of Sunn pest, Eurygaster integriceps, $\alpha$-amylases by $\alpha$-amylase inhibitors (T- $\alpha \mathrm{AI}$ ) from Triticale. J. Insect Sci. 10 http://insectscience.org/10.179 [Accessed: June 28, 2013].

Ogendo J.O., Kostyukovsky M., Ravid U., Matasyoh J.C., Deng A.L., Omolo E.O., Kariuki S.T., Shaaya E. 2008. Bioactivity of Ocimum gratissimum oil and two constituents against five insect pests attacking stored food products. J. Stored Prod. Res. 44 (4): 328-334.

Olga S., Fevizi U., Ekrem E. 2006. Effects of Cypermethrin on total body weight, glycogen, protein, and lipid contents of Pimpla turionellae L. (Hymenoptera: Ichneumonidae). Belg. J. Zool. 136 (1): 53-58.

Pavela R. 2006. Insecticidal activity of essential oils against cabbage aphid (Brevicoryne brassicae). J. Essent. Oil Bearing Plants 9 (2): 99-106.

Rajendran S., Muralidharan N. 2005. Effectiveness of allyl acetate as a fumigant against five stored grain beetle pests. Pest Manag. Sci. 61 (1): 97-101.

Regnault-Roger C. 1997. The potential of botanical essential oils for insect pest control. Integr. Pest. Manag. Rev. 2 (1): 25-34.

Regnault-Roger C., Ribodeau M., Hamraoui A., Bareau I., Blanchard P., Gil-Munoz M.I., Barberan F.T. 2004. Polyphenolic compounds of Mediterranean Lamiaceae and investigation of orientional effects on Acanthoscelides obtectus (Say). J. Stored Prod. Res. 40 (4): 395-408.

Rosman V., Kalinovic I., Korunic Z. 2007. Toxicity of naturally occurring compounds of Lamiaceae and Lauraceae to three stored product insects. J. Stored Prod. Res. 43 (4): 349-355.

Sadek M.M. 2003. Antifeedant and toxic activity of Adhatoda vasica leaf extract against Spodoptera littoralis (Lep.: Noctuidae). J. Appl. Entomol. 127 (7): 396-404.

Saleem M.A., Shakoori A.R. 1987. Joint effects of Dimilin and Ambush on enzyme activities of Tribolium castaneum larvae. Pestic. Biochem. Physiol. 29 (2): 127-137.

Sancho E., Ferrando M. D., Fernandez C., Andreu E. 1998. Liver energy metabolism of Anguilla anguilla after exposure to fenitrothion. Ecotoxicol. Environ. Saf. 41 (2): 168-175.

SAS Institute. 1997. SAS/STAT Users̀ Guide for Personal Computers, SAS Institute, Cary NC, 18 pp.

Saxena R.C., Dixit O.P., Harnash V. 1992. Insecticidal action of Lantana camara against Callosobruchus chinensis (Coleoptera: Bruchidae). J. Stored Prod. Res. 28 (4): 279-281.

Schmidt G.H., Rembold H., Ahmed A.I.A., Breuer M. 1998. Effect of Melia azedarach fruit on juvenile hormone titer and protein content in the hemolymph of two species of noctuid Lepidoptera larvae (Insecta: Lepidoptera: Noctuidae). Phytoparasitica 26 (4): 283-291.

Scriber J.M., Slansky F. 1981. The nutritional ecology of immature insects. Annu. Rev. Entomol. 26: 183-211.

Schmutterer H. 1990. Fecundity reduction and sterilizing effect of neem seed kernel extracts in the Colorado potato beetle Leptinotarsa decemlineata. p. 351-360. In: Proc. 3rd Int. Neem Conf. (INC90), Nairobi, Kenya, 351 pp. 
Senthil Nathan S., Gene Chung P., Murugan K. 2004. Effect of botanical insecticides and bacterial toxins on the gut enzyme of the rice leaffolder Cnaphalocrocis medinalis. Phytoparasitica 32 (5): 433-443.

Senthil Nathan S., Chung P.G., Murugan K. 2006. Combined effect of biopesticides on the digestive enzymatic profiles of Cnaphalocrocis medinalis (Guenee) (the rice leaffolder) (Insecta: Lepidoptera: Pyralidae). Ecotox. Environ. Safe. 64 (3): 382-389.

Seyoum E., Bateman R.P., Charnley A.K. 2002. The effect of Metarhizium anisopliae var. acridum on haemolymph energy reserves and flight capability in the desert locust, Schistocerca gregaria. J. Appl. Entomol. 126 (2-3): 119-124.

Shaaya E., Kostyukovski M., Eilberg J., Sukprakarn C. 1997. Plant oils as fumigants and contact insecticides for the control of stored-product insects. J. Stored Prod. Res. 33 (1): 7-15.

Shaaya E., Ravid U., Paster N., Juven B., Zisman U., Pissarev V. 1991. Fumigant toxicity of essential oils against four major stored product insects. J. Chem. Ecol. 17 (3): 499-501.

Shekari M., Jalali Sendi J., Etebari K., Zibaee A., Shadparvar A. 2008. Effects of Artemisia annua L. (Asteracea) on nutritional physiology and enzyme activities of elm leaf beetle, Xanthogaleruca luteola Mull. (Coleoptera: Chrysomelidae). Pestic. Biochem. Physiol. 91 (1): 66-74.

Slansky F.J., Scriber J.M. 1985. Food consumption and utilization. p. 87-163. In: “Comprehensive Insect Physiology, Biochemistry, and Pharmacology" (G.A. Kerkut, L.I. Gilbert, eds.). Vol. 4. Pergamon Press, Oxford, 849 pp.

Sujitha S.B. Joseph B., Sumi P.S. 2010. Medicinal plants and its impact of ecology, nutritional effluents and incentive of di- gestive enzymes on Spodoptera litura (Fabricious). Asian J. Agric. Res. 4 (4): 204-211.

Terra W.R., Ferriera C. 2005. Biochemistry of digestion. p. 171224. In: “Comprehensive Molecular Insect Science” (I. Lawrence Gilbert, K. Iatrou, S. Sarjeet Gill, eds.). Vol. 3. Elsevier, Amsterdam, $330 \mathrm{pp}$.

Tsujita T., Ninomiya H., Okuda H. 1989. P-nitrophenyl 865 butyrate hydrolyzing activity of hormone-sensitive lipase 866 from bovine adipose tissue. J. Lipid Res. 30 (7): 997-1004.

Van Asperen K. 1962. A study of housefly esterases by mean of sensitive colorimetric method. J. Insect. Physiol. 8 (4): 401-416.

Vanhaelen N., Haubruge E., Lognay G., Francis F. 2001. Hoverfly glutathione S-transferases and effect of Brassicaceae secondary metabolites. Pestic. Biochem. Physiol. 71 (3): 170177.

Vijayaraghavan C., Sivakumar C., Zadda Kavitha M., Sivasubramanian P. 2010. Effect of plant extracts on biochemical components of cabbage leaf webber, Crocidolomia binotalis Zeller. J. Biopesticid. 3 (1): 275-277.

Waldbauer G.P. 1968. The consumption and utilization of foods by insects. Adv. Insect Physiol. 5: 229-288.

Yual B., Holliday Hanson M., Washino R.K. 1994. Energy budget of swarming male mosquitoes. Ecol. Entomol. 19 (10): 74-78.

Zibaee A., Bandani A.R. 2010. Effects of Artemisia annua L. (Asteracea) on digestive enzymes profiles and cellular immune reactions of sun pest, Eurygaster integriceps (Heteroptera: Scutellaridae), against Beauvaria bassiana. Bull. Entomol. Res. 100 (2): 185-196. 